Review Article レビュー論文ーシリーズ 114

Invited Peer-Reviewed Article 招待査読論文

\title{
The Originator Effect of User Ideated Products ユーザー創造製品の発案者効果
}

\author{
Shoo Okada ${ }^{* 1}$ \\ 法政大学大学院 経営学研究科 博士後期課程 \\ 岡田 庄生
}

${ }^{* 1}$ Graduate School of Business Administration, Hosei University, shoo.okada@gmail.com

\begin{abstract}
A growing number of consumers are participating in the new product development process with companies. Companies can both obtain product ideas from users and also increase the purchase intent of consumers who see information about the product that has been conceived of by an actual user. Consumers infer the quality of products when they see a display in which product ideas are created by users rather than companies. In this paper, we describe this quality inference as an "Originator Effect" and review the relevant prior research. The previous investigations have been based on the following two trends: (1) mediating factor research to explore the background of the "Originator Effect", and (2) boundary condition research to investigate the conditions under which the "Originator Effect" is lost. In addition, among future investigations to expand the "Originator Effect" research, the author claims three subjects: (1) investigations of mediation factors, (2) investigations of boundary conditions, and (3) investigations of both mediation factors and boundary conditions.
\end{abstract}

Keyword : Co-creation, Idea creation, New product development, Customer orientation, Innovation

要約 : 企業の新製品開発プロセスに参加するユーザー（消費者）が増えている。企業はユーザーから製品アイデアを得るだけで なく, ユーザーのアイデアから生まれた製品であるという情報を表示することで, その表示を見た消費者の購買意向を高めるこ とが可能である。本稿では, 製品アイデアの発案者が企業ではなくユ一ザーであることを明示することで, 消費者が購買の意思 決定に影響を与える効果を「発案者効果 (Originator Effect)」と名付け, その既存研究を整理する。発案者効果の既存研究は, 以下の 2 つの潮流, すなわち（1）発案者効果の背景を探る「媒介要因研究」，(2) 発案者効果が失われる条件を探る「境界条 件研究」に分類して整理できる。また, 発案者効果研究の発展のため, 今後の研究課題として, (1) 媒介要因研究の課題, (2) 境界条件研究の課題, (3) 両研究における研究方法の課題を提示した。

キーワード : 共創, アイデア創造, 新製品開発, 顧客志向, イノベーション

Information : Received 25 May 2019; Accepted 17 June 2019

\section{I. はじめに}

近年, 様々な企業がユーザーとの共創活動を通じて, ユーザーのアイデアをイノベーションの源泉として取り 入れている (Prahalad \& Ramaswamy, 2004; von Hippel, 2005)。特に, インターネットを通じた, ユーザーによ る新製品開発プロセスへの参加が加速している（Fuchs, Prandelli, \& Schreier, 2010; Sawhney, Verona, \& Prandelli, 2005)。例えば, DELL やスターバックス（Bayus, 2013）, LEGO (Jensen, Hienerth, \& Lettl, 2014)，良品計画
(Nishikawa \& Honjo, 2011) など, 数多くの企業がユー ザーのアイデアを製品開発に取り入れて, 新製品アイデ アの質を高めている（Poetz \& Schreier, 2012）。

また，ユーザーのアイデアによって開発された新製品 と共に,「お客様のアイデアから生まれた」といった情報 を表示することで, 店頭などでその情報を初めて見る一 般の消費者, すなわち「観察消費者」の購買意向や実際 の売上げを高める効果があることも明らかになっている (Dahl, Fuchs, \& Schreier, 2015; Fuchs \& Schreier, 2011; Nishikawa, Schreier, Fuchs, \& Ogawa, 2017)。製品開発プ ロセスに参加したユーザーが, 自らが関与した製品の購 
Review Article レビュー論文ーシリーズ 114

買意向が高まることはすでに明らかになっているが （Fuchs et al., 2010; Moreau \& Herd, 2010），観察消費者で すら，ユーザーがアイデアを創造した製品だという情報 を知ることで購買意向が高まるのは, 企業のマーケター にとって朗報である。なぜなら，開発プロセスに参加で きるユーザーの人数は, インターネットの発達により増 加したとはいえ，市場全体からみるとごくわずかだから である（Fuchs \& Schreier, 2011）。例えば, マクドナルド が 2011 年にドイツで行った, ユーザーが新しいハンバー ガーのアイデア創造に参加するキャンペーンでは, 実際 にアイデア創造に参加したユーザーは，マクドナルドに 日々訪れる消費者のうちわずか $4 \%$ であり，残りの $96 \%$ は店舗などで初めて目撃する観察消費者であった (Kristal, Baumgarth, Behnke, \& Henseler, 2016)。より大 きな市場の獲得を考える上で，ユーザー創造製品に関す る情報が観察消費者に与える影響を明らかにすることは, 実務上の重要な課題といえる。また，ユーザー創造製品 の情報表示が持つ影響に着目した研究は 2011 年以降に 本格化しており, 様々な研究が進んでいるものの全体を 俯瞰するレビュー論文はまだ存在していない。これまで の研究を整理して, 今後の研究課題を明らかにすること は学術的な意義がある。

本稿の目的は，ユーザー創造製品の情報が，観察消費 者の購買意向に与える影響について行われた研究を整理 し，今後の研究課題について明らかにしていくことであ る。観察消費者がユーザー創造製品を選好する心理的要 因の基本的な構造は, 消費者の推論（inference）によっ て説明することができる（Nishikawa et al., 2017）。消費 者が製品の購入を判断する際に，価格やスペックなど事 前に知り得る品質だけでなく，使い勝手やフィット感な ど事前には得られない品質も必要とする場合がある。そ の際，消費者は限られた情報から製品の品質を推論する (Kardes, Posavac, \& Cronley, 2004)。推論の代表的な例と して,「フランス産のワイン」「ベルギー産のチョコレー ト」といった原産国を表示することで購買意向を高める 「原産国効果 (Country-of-Origin Effect)」(Bilkey \& Nes, 1982）があげられる。本稿で取り上げるユーザー創造製 品の表示が持つ効果は, アイデアの発案者がユーザーで あることを明示することで生じる推論の一種だといえる。
そこで，本稿では，ユーザーがアイデアを創造した製品 であるという情報による推論がもたらす効果のことを「発 案者効果 (Originator Effect)」と呼ぶこととする ${ }^{1)}$ 。

本稿の構成は, 以下の通りである。ユーザー創造製品 の発案者効果に関する既存研究を 2 つの潮流, すなわ ち, 効果の背景を探る「媒介要因研究」と, 効果が失わ れる条件を探る「境界条件研究」に分類して, 第二章と 第三章にて整理する。第四章では, まとめと今後の研究 課題について述べる。

\section{II. 研究潮流(1) : 発案者効果の背景を探る「媒介要 因研究」}

本章では, ユーザー創造製品における発案者効果の背 景を探る「媒介要因研究」についての既存研究を整理す る。消費者が限られた情報から製品の品質を推論する 際に行われている情報処理は，三段論法（syllogistic inference）である（Kardes et al., 2004）。三段論法とは， 例えば,「飲料 A はビタミンが豊富である」「ビタミンは 体に良い」「つまり，飲料 A は体に良い」というような 論法である。ユーザー創造製品の発案者効果も同様に, 「ビタミン」のような媒介要因を経て, 購買意向が高まっ ていると考えられる。発案者効果の媒介要因を探る様々 な既存研究を整理すると，4つの媒介要因，すなわち， （1）企業要因，（2）ブランド要因，（3）製品要因，（4） 消費者要因が存在するといえる。

\section{1. 企業要因}

まず、既存研究では, 企業の顧客志向およびイノベー ション能力が媒介要因であることが明らかになっている。 Fuchs and Schreier（2011）は, T シャツ, 家具, 自転車 を対象として, ユーザー創造製品の発案者効果について の実験を行った。その研究の中で, 観察消費者は, ユー ザー創造製品を製造する企業へ好意的な態度を持つこと や，その企業が高い顧客志向を持っているという認識を 高めている事が確認された2)。

さらに, Schreier, Fuchs, and Dahl（2012）は観察消費 者への定性的なインタビュー調査と定量的な調査を通じ 
て，企業のイノベーション能力（Luo \& Bhattacharya, 2006）に対する認識が，購買意向に対して媒介効果があ ることを明らかにしている。観察消費者は，企業がユー ザーとの共創活動を通じて, アイデアの量や多様性, ユー ザーニーズの把握力などイノベーション能力を高めてい るだろうと推論し，その結果として購買意向を高めてい ることが明らかになった。同様の結果は, Costa and Coelho do Vale（2018）が行った研究でも確認された。

ただし，これらの研究で行われた実験の多くは企業名 やブランド名が隠された状態であり，実際のマーケット での状態とは違うという批判がある。 Meißner, Haurand, and Stummer（2017）が行った，アップルとノキアとい う実在する 2 つブランドのスマートフォンを対象に, イノベーション能力を媒介要因として実施した調査では, ユーザー創造製品は企業創造製品と比べて有意に高い購 買意向を示さなかった。また，企業のイノベーション能 力は購買意向に対して部分的な媒介効果は示したものの, 十分に媒介効果が説明できてはいない。この研究は，次 項で見るように，実在するブランドの場合，観察消費者 が既に抱いているブランドに対する認識が，ユーザー創 造製品の発案者効果に影響を与える可能性を示唆したと いえる。

\section{2. ブランド要因}

こうしたブランドに対する認識を媒介要因としたも のが, 次の研究群である。van Dijk, Antonides, and Schillewaert（2014）は，良く知られるブランドと架空の ブランドを題材として，ユーザー創造製品の発案者効果 を調査した。その結果，ユーザー創造製品の発案者効果 はブランドの誠実さ（Aaker, 1997）が媒介要因となり, 購買意向に正の影響を与えることが確認された。また， 観察消費者がブランドを認知していたか否かは，ブラン ドに対する認識と購買意向に影響を与えていなかった。

ところが， Kristal et al.（2016）が行った調査では，異 なる結論が得られた。ナイキとケルンエネルギーシリア ルという 2 つ実在するブランドを使って行われた調査 の結果，ユーザー創造製品情報の表示は，ケルンエネル ギーシリアルのブランドエクイティ（Aaker, 1991）に正 の影響を与えたが，ナイキに対しては有意な結果を示さ
なかった。Liljedal（2016）も，観察消費者が持つブラン ドに対する認識はユーザー創造製品の発案者効果に大き な影響を与えることを，実証実験を通じて明らかにして いる。このように，実際のブランド名を使ったブランド に対する認識を媒介要因とした研究が行われているもの の, 一貫した結論が出ていない。

\section{3. 製品要因}

次に, 製品品質に対する認識を媒介要因とした研究で ある（Nishikawa et al., 2017）。それは，ユーザー創造製 品の発案者効果をフィールド実験によって実証した初め ての研究でもある。実験に使用されたのは，無印良品ブ ランドから新たに発売された電気製品（ブザーや万歩計） と食品（スナック菓子）である。電気製品によるフィー ルド実験では，ユーザー創造情報をPOP に提示した店舗 の売り上げが，そうでない店舗に比べて 1.2 倍高かった。 さらに，追加的な実験室実験において，ユーザー創造製 品の情報表示が消費者の購買意向を高める媒介要因とし て，2つの製品要因に関連した媒介変数，すなわち（1） 製品の品質，（2）新しさへの認識について調査を行って いる。その結果, ユーザー創造製品の情報表示がユーザー 創造製品の選択に与える正の影響は，製品の品質によっ て完全に媒介しており, 新しさは有意な結果を示さなかっ た。つまり，製品の品質が媒介要因であることが実証さ れた。

\section{4. 消費者要因}

最後に, 企業側に主な要因を求めるのではなく，消費 者側に媒介要因を求める研究群である。Dahl et al. (2015) は，ユーザー創造製品の情報が観察消費者の購買意向に 与える正の影響は, 企業への社会的アイデンティティ (Tajfel, 1982) によって媒介されることを実証的に明らか にした。観察消費者はただ単に企業の能力を評価してい るだけでなく，ユーザー創造製品を製造する企業と自分 自身との結びつき，すなわち社会的アイデンティティを 高め，あたかも自分自身が企業と共同で製品開発をした かのような感覚を持ち，その結果として購買意向が高ま ることが明らかになった。

また，Wang, Noble, Dahl, and Park（2019）による最近 
Review Article レビュー論文ーシリーズ 114

の研究では，ユーザー創造製品の広告において，企業に よる説得的メッセージと, ユーザーのアイデア誕生ストー リーを同時に記載した上で，両者の関係性に焦点をあて た調査を行っている ${ }^{3)}$ 。その結果, 企業メッセージとユー ザーストーリーの志向性が一致している場合よりも不一 致な場合の方が, 購買意向が高まることが明らかになっ た。さらに, 情報の不一致は, 消費者が広告の内容と自 分の経験を関連づける「自己参照」(Escalas, 2007) と呼 ばれる認知プロセスの高まりを媒介要因として, 購買意 向に正の影響があることを確認している。つまり，志向 性が不一致である方が，観察消費者がより深く広告の情 報と自分の経験を関連づけるので，購買意向が高まるの である。

\section{III. 研究潮流(2)：発案者効果が失われる条件を探る 「境界条件研究」}

本章では，発案者効果の有効性が失われる条件に関す る研究を以下の 2 つの要因, すなわち（1）技術要因, （2）社会要因に分けて整理する。

\section{1. 技術要因}

まず，技術の複雑さの程度が境界条件となる。Schreier et al.（2012）は，技術的複雑さが高い製品（家電製品, ガーデニング用電子機器, ロボット玩具）と，複雑さが 低い製品（Tシャツ，トイレタリー用品，アウトドアス ポーツ用品）を用いて，ユーザー創造製品の発案者効果 を調査した。その結果，複雑さが低い製品カテゴリは ユーザー創造製品の情報表示が購買意向に対して正の影 響を与えていたが，複雑さが高い製品カテゴリでは有意 な結果を示さなかった。同様の傾向が, Costa and Coelho do Vale（2018）が行った，製品の複雑さを 3 段階に分 け, $\mathrm{iPad}$ カバー (複雑性低), スニーカー (中), スマー トウォッチ（高）を使用した実験においても示されてい る。複雑性が低い製品ではユーザー創造製品の情報表示 が購買意向に正の影響を与えていたが，複雑さが中と高 の製品では効果が見られなかった。

\section{2. 社会要因}

社会要因として, 既存研究では, ステータスと権力格 差の 2 つが発案者効果の境界条件であることが明らかに なっている。Fuchs, Prandelli, Schreier, and Dahl（2013） は, ファッション分野において, 高ステータスなブラン ド（プラダやグッチ，ルイ・ヴィトンなど）や製品カテ ゴリ（ハンドバッグ，ドレスシャツ，レザーシューズ） を対象として，ユーザー創造製品の発案者効果について 調査を行った。その結果, 高ステータスなブランドや製 品カテゴリにおいては, 発案者効果は負の影響を与える ことが明らかになった。ラグジュアリーブランドは社 会的なステータスのシグナルに大きく関与している (Wernerfelt, 1990)。そのため, デザインの素人である ユーザーがデザインを創造しているという情報が，消費 者が他者に対して優越感を感じる「代理感情」(Locke, 2003）と呼ばれる感情に対して負の影響を及ぼし，製品 選択に対して負の影響を与えることが Fuchs et al. （2013）によって実証された。

また，Paharia and Swaminathan（2019）は，ユーザー 創造製品の発案者効果を国家単位で比較し, 権力格差 (Power Distance）がその有効性に影響することを明らか にした。権力格差とは, 国家において国民が権力の不平 等を予期し，受け入れている程度のことを指す (Hofstede, Hofstede, \& Minkov, 2010/2013)。研究では, 権力格差の 高い国家（グアテマラ）と，低い国家（オーストリア） において，ユーザーおよび企業が創造したサービスに関 する Facebook 広告を表示するフィールド実験を行い, 権 力格差の高い国ではユーザー創造サービスが, 権力格差 の低い国では企業創造サービスが選ばれることが確認さ れた。つまり，上下関係を受け入れる度合いが高い国は， ユーザーが企業の製品開発に関与すべきではないと考え る国民が多いため, ユーザー創造製品の発案者効果は弱 まる。

\section{IV. 本研究のまとめと今後の研究課題}

ここまで，ユーザー創造製品の発案者効果が観察消費 者の購買意向に与える影響に関する既存研究を, 媒介要 
因研究と境界条件研究の 2 つに分類して整理してきた （表 1)。その結果，媒介要因研究においては，企業の顧 客志向やイノベーション能力, ブランド，製品品質など の媒介要因が明らかになりつつあると共に，消費者の社 会的アイデンティティや自己参照といった，より消費者 側に近い要因の研究へとステージが進んでいた。また， 境界条件研究においては，技術要因に加えて，ステータ スや権力格差などの社会要因へと研究の幅が広がってい ることが確認できた。ここまでの研究を踏まえた上で, 本章では，それぞれの潮流を発展させるために，今後の 研究課題を述べる。

第一に，媒介要因研究においては，製品そのものに着 目した媒介要因の研究が課題である。企業の顧客志向や イノベーション能力など，企業に関連する媒介要因を対 象とした研究の多さと比較すると，製品に関連する媒介 要因の研究はいまだ少ない。Nishikawa et al.（2017）は 製品品質が媒介要因であることを明らかにした点で大き な貢献はあるものの，品質を測定する質問の内容が，ア イデアの素晴らしさやユーザーニーズのフィットなど複 数の要因が混在しており，製品レベルの要因を十分に明 らかにしておらず，限界がある。例えば，ユーザー創造 情報が製品の有用性や新奇性（Im \& Workman, 2004）な どの認識に対してどのように影響を与えるのかを明らか にすることは大きな意義があると考える。
第二に, 境界条件研究においては, 製品カテゴリや外 部要因を発展させた研究が求められる。例えば, 消費者 行動分野において蓄積のある, 最寄品, 買回品, 専門品 といった伝統的な製品カテゴリ（Coepland, 1923）や, 功 利主義的, 快楽主義的（Dhar \& Wertenbroch, 2000）と いった消費者の購買動機と関連した製品カテゴリを対象 とした研究を通じて，新たな境界条件を発見することが 期待できる。また，政治要因や経済要因など，経営学の 分野で蓄積のある外部要因研究との関連性を明らかにす ることも，境界条件を発展させる可能性をもつと考えら れる。

第三に, 媒介要因研究および境界条件研究の双方を発 展させる視点として, 表示方法の幅を広げた研究の必要 性について述べる。既存研究の多くは，ユーザー創造製 品に関する情報を, POP や数行の文章などの限られた情 報量で伝えた上で，購買意向を計測してきた。しかし， インターネットの発達により, 企業が消費者に伝達可能 な情報量は格段に増えている。ユーザーのアイデア創造 ストーリーを用いた Wang et al.（2019）の研究のように, ユーザー創造情報の表示方法を, 長い文章や画像, 動画 などの情報量の多い方法で表示したり，紙媒体とスマー トフォンなど異なるメディアでの表示に着目するなど， 多様な表示方法の効果を分析することで新たな媒介要因 や境界条件を明らかにすることも, 今後の研究課題で

\begin{tabular}{|c|c|c|}
\hline 研究潮流 & 要因 & 主な既存研究 \\
\hline \multirow{4}{*}{ (1)媒介要因研究 } & 1. 企業要因 & $\begin{array}{l}\text { Fuchs and Schreier (2011) } \\
\text { Schreier et al. (2012) } \\
\text { Meißner et al. (2017) } \\
\text { Costa and Coelho do Vale (2018) }\end{array}$ \\
\hline & 2. ブランド要因 & $\begin{array}{l}\text { van Dijk et al. (2014) } \\
\text { Kristal et al. (2016) } \\
\text { Liljedal (2016) }\end{array}$ \\
\hline & 3. 製品要因 & Nishikawa et al. (2017) \\
\hline & 4. 消費者要因 & $\begin{array}{l}\text { Dahl et al. (2015) } \\
\text { Wang et al. (2019) }\end{array}$ \\
\hline \multirow[t]{2}{*}{ (2)境界条件研究 } & 1. 技術要因 & $\begin{array}{l}\text { Schreier et al. (2012) } \\
\text { Liljedal (2016) } \\
\text { Costa and Coelho do Vale (2018) }\end{array}$ \\
\hline & 2. 社会要因 & $\begin{array}{l}\text { Fuchs et al. (2013) } \\
\text { Paharia and Swaminathan (2019) }\end{array}$ \\
\hline
\end{tabular}

筆者作成 
ある。

ユーザーによる新製品開発プロセスへの参加は，イン ターネットの発達と共に今後も益々増加するであろう。 ユーザー創造製品の発案者効果の研究は, 単なるマーケ ティング施策の有効性を確認するだけのものではなく, ユーザーとの共創活動が世の中からどのように捉えられ ているのかを明らかにすることでもある。よって，この 研究が拡大することは, マーケティング領域の実務や研 究への貢献のみならず，ユーザーと企業との共創関係の 未来を解き明かすことに対しても，大きな利益を生み出 すことが期待される。

\section{謝辞}

担当編集委員の西川英彦先生からの本特集への招待, および丁寧かつ有意義なコメントに対して，心から感謝 いたします。

\section{注}

1）なお，ユーザー自身がアイデアを創造する場合と，ユーザー が市場に出すべき製品を複数候補から選択する場合の $2 つ$ の方法を区別して分析を行っている研究もいくつか存在す るが (e.g. Fuchs \& Schreier, 2011; Liljedal \& Dahlén, 2018), 既存研究の主流はユーザー自身がアイデアを創造するケー スを分析対象としている。そのため，本稿では，ユーザー がアイデアを創造した製品の発案者効果について議論する こととする。

2) Fuchs and Schreier（2011）は，企業要因として顧客志向の 重要性を明らかにしているが, 顧客志向を媒介変数とした 媒介分析を行っているわけではなく，この点において限界 がある。

3）実験では，ユーザーのアイデア創造ストーリーとして，ア イデアを創造したユーザーの名前や，アイデア創造のきっ かけとなる原体験，そのときの気持ちなどが物語り調で記 述されていた。

\section{References}

Aaker, D. A. (1991). Managing brand equity: Capitalizing on the value of a brand name. New York: Free Press.（陶山計介 - 中 田善啓・尾崎久仁博・小林哲（訳）（1994）。『ブランド・エ クイテイ戦略一競争優位をつくりだす名前, シンボル， ス ローガン一』ダイヤモンド社)

Aaker, J. (1997). Dimensions of brand personality. Journal of Marketing Research, 34(3), 347-356.

Bayus, B. L. (2013). Crowdsourcing new product ideas over time: An analysis of the dell ideastorm community. Management Science, 59(1), 226-244.

Bilkey, W. J., \& Nes, E. (1982). Country-of-origin effects on product evaluations. Journal of International Business Studies, 13(1), 89-100.

Coepland, M. T. (1923). Relation of consumers' buying habits to marketing methods. Harvard Business Review, 1(3), 282-289.

Costa, C., \& Coelho do Vale, R. (2018). To tell or not to tell? The impact of communicating consumer participation in new product development. Journal of Product and Brand Management, 27(2), 158-171.

Dahl, D. W., Fuchs, C., \& Schreier, M. (2015). Why and when consumers prefer products of user-driven firms: A social identification account. Management Science, 61(8), 1978-1988.

Dhar, R., \& Wertenbroch, K. (2000). Consumer choice between hedonic and utilitarian goods. Journal of Marketing Research, $37(1), 60-71$.

Escalas, J. E. (2007). Self-referencing and persuasion: Narrative transportation versus analytical elaboration. Journal of Consumer Research, 33(4), 421-429.

Fuchs, C., Prandelli, E., \& Schreier, M. (2010). The psychological effects of empowerment strategies on consumers' product demand. Journal of Marketing, 74(1), 65-79.

Fuchs, C., Prandelli, E., Schreier, M., \& Dahl, D. W. (2013). All that is users might not be gold: How labeling products as user designed backfires in the context of luxury fashion brands. Journal of Marketing, 77(5), 75-91.

Fuchs, C., \& Schreier, M. (2011). Customer empowerment in new product development. Journal of Product Innovation Management, 28(1), 17-32.

Hofstede, G., Hofstede, J. G., \& Minkov, M. (2010). Cultures and organizations: Software of the mind, third edition. New York: McGraw-Hill Education.（岩井八郎・岩井紀子（訳）（2013）. 『多文化世界一違いを学び未来への道を探る一原書第 3 版』 有斐閣）

Im, S., \& Workman, J. P. (2004). Market orientation, creativity, and new product performance in high-technology firms. Journal of Marketing, 114(68), 114-132.

Jensen, M. B., Hienerth, C., \& Lettl, C. (2014). Forecasting the commercial attractiveness of user-generated designs using online data: An empirical study within the LEGO user community. Journal of Product Innovation Management, 31(S1), 75-93.

Kardes, F. R., Posavac, S. S., \& Cronley, M. L. (2004). Consumer inference: A review of processes, bases, and judgment contexts. Journal of Consumer Psychology, 14(3), 230-256.

Kristal, S., Baumgarth, C., Behnke, C., \& Henseler, J. (2016). Is cocreation really a booster for brand equity? The role of cocreation in observer-based brand equity (OBBE). Journal of Product and Brand Management, 25(3), 247-261.

Liljedal, K. T. (2016). The effects of advertising consumer cocreated new products: A brand-alliance framework model can predict perceptions about co-created brands and their creators. Journal of Advertising Research, 56(1), 53-63.

Liljedal, K. T., \& Dahlén, M. (2018). Consumers' response to other consumers' participation in new product development. Journal of Marketing Communications, 24(3), 217-229. 
Locke, K. D. (2003). Status and solidarity in social comparison: Agentic and communal values and vertical and horizontal directions. Journal of Personality and Social Psychology, 84(3), $619-631$.

Luo, X., \& Bhattacharya, C. B. (2006). Corporate social responsibility, customer satisfaction, and market value. Journal of Marketing, 70(4), 1-18.

Meißner, M., Haurand, M. D., \& Stummer, C. (2017). With a little help from my customers: The influence of customer empowerment on consumers' perceptions of well-established brands. International Journal of Innovation Management, 21(6), 367-394.

Moreau, C. P., \& Herd, K. B. (2010). To each his own? How comparisons with others influence consumers' evaluations of their self-designed products. Journal of Consumer Research, 36(5), 806-819.

Nishikawa, H., \& Honjo, S. (2011). Tayousei no management: Crowdsourcing of Muji. Japan Marketing Journal, 30(3), 3549. (西川英彦・本條晴一郎 (2011).「多様性のマネジメン ト一無印良品のクラウドソーシングー」『マーケティング ジャーナル』30(3), 35-49) (In Japanese)

Nishikawa, H., Schreier, M., Fuchs, C., \& Ogawa, S. (2017). The value of marketing crowdsourced new products as such: Evidence from two randomized field experiments. Journal of Marketing Research, 54(4), 525-539.

Paharia, N., \& Swaminathan, V. (2019). Who is wary of user design? The role of power-distance beliefs in preference for userdesigned products. Journal of Marketing, 83(3), 91-107.

Poetz, M. K., \& Schreier, M. (2012). The value of crowdsourcing: Can users really compete with professionals in generating new product ideas? The Journal of Product Innovation Management, 29(2), 245-256.

Prahalad, C. K., \& Ramaswamy, V. (2004). Co-creation experiences: The next practice in value creation. Journal of Interactive Marketing, 18(3), 5-14.

Sawhney, M., Verona, G., \& Prandelli, E. (2005). Collaborating to create: The internet as a platform for customer engagement in product innovation. Journal of Interactive Marketing, 19(4), 417.

Schreier, M., Fuchs, C., \& Dahl, D. W. (2012). The innovation effect of user design: Exploring consumers' innovation perceptions of firms selling products designed by users. Journal of Marketing, 76(5), 18-32.

Tajfel, H. (1982). Social psychology of intergroup relations. Annual Review of Psychology, 33(1), 1-39.

van Dijk, J., Antonides, G., \& Schillewaert, N. (2014). Effects of cocreation claim on consumer brand perceptions and behavioural intentions. International Journal of Consumer Studies, 38(1), 110-118.

von Hippel, E. (2005). Democratizing innovation. Boston: MIT Press.（サイコム・インターナショナル（訳）（2006）。『民 主化するイノベーションの時代一メーカー主導からの脱皮 一』ファーストプレス)

Wang, H. S., Noble, C. H., Dahl, D. W., \& Park, S. (2019).
Successfully communicating a cocreated innovation. Journal of Marketing, 83(4), 38-57.

Wernerfelt, B. (1990). Advertising content when brand choice is a signal. The Journal of Business, 63(1), 91-98.

\section{岡田 庄生（おかだ しょうお）}

法政大学大学院 経営学研究科 博士後期課程。 修士 (経営学)。株式会社博報堂 (本務), 駒沢大学 (非常 勤講師)。専門は, 消費者行動論, マーケティング・コミュ ニケーション論, ブランド論。 